\title{
Larvicidal activity of a neem tree extract (Neemarin) against mosquito larvae in the Islamic Republic of Iran
}

H. Vatandoost ${ }^{1}$ and V.M. Vazirit

$$
\begin{aligned}
& \text { الفعالية المضادة لليرقات في خلاصَة شجر النيم على يرقات البعوض في جمهورية إيران الإسلامية } \\
& \text { حسن وطن دوست، وحيدة معين وزيري في لاصني }
\end{aligned}
$$

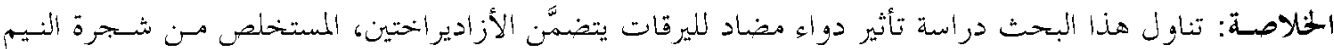

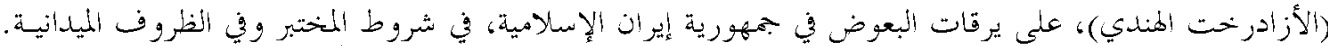

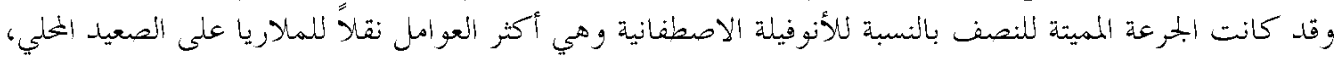

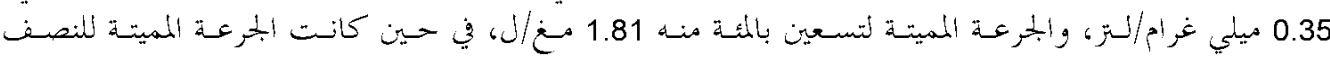

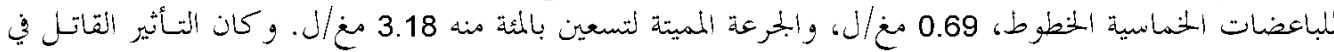

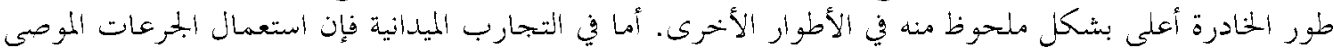

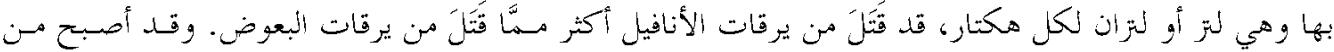

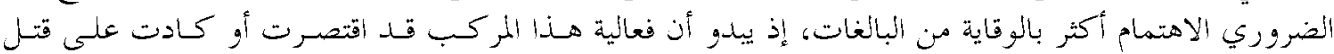

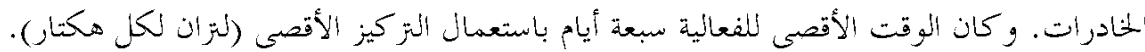

ABSTRACT An insecticide containing azadirachtin, a neem tree (Azadirachta indica) extract, was tested against mosquito larvae in the Islamic Republic of Iran under laboratory and field conditions. LC $_{50}$ and LC $_{90}$ values for Neemarin were 0.35 and $1.81 \mathrm{mg} / \mathrm{L}$ for Anopheles stephensi, the main local malaria vector, and 0.69 and $3.18 \mathrm{mg} / \mathrm{L}$ for Culex quinquefasciatus. The mortality in the pupal stage was significantly higher than the other stages. In field trials, using recommended dosages of 1 and $2 \mathrm{~L} /$ hectare, mortality of Anopheles spp. larvae was also higher than Culex spp. Prevention of adult emerged and pupal mortality was the main activity of this compound. The maximum time of efficacy was 7 days at the highest concentration $(2 \mathrm{~L} /$ hectare $)$.

\begin{abstract}
Activité larvicide d'un extrait du margousier (Neemarin) contre les larves de moustiques en République islamique d'Iran

RÉSUMÉ Un insecticide contenant de l'azadirachtine, un extrait du margousier (Azadirachta indica), a été testé en laboratoire et sur le terrain pour la lutte contre les larves de moustiques en République islamique d'Iran. Les valeurs $\mathrm{CL}_{50}$ et $\mathrm{CL}_{90}$ pour le Neemarin étaient de 0,35 et $1,81 \mathrm{mg} / \mathrm{L}$ pour Anopheles stephensi, le principal vecteur local du paludisme, et 0,69 et $3,18 \mathrm{mg} / \mathrm{L}$ pour Culex quinquefasciatus. La mortalité au stade nymphe était significativement plus élevée qu'aux autres stades. Dans les essais sur le terrain, en utilisant les dosages recommandés de 1 et $2 \mathrm{~L} /$ hectare, la mortalité des larves d'Anopheles spp. était également plus élevée que pour Culex spp. La prévention de l'éclosion imaginale et la mortalité des nymphes constituaient la principale activité de ce composé. Le temps d'efficacité maximum était de sept jours à la concentration la plus élevée (2 L/hectare).
\end{abstract}

${ }^{1}$ School of Public Health and Institute of Health Research, Tehran University of Medical Science, Tehran, Islamic Republic of Iran.

Received: 22/10/02; accepted: 18/08/03

المحلة الصحية لشرق المتو سط، منظمة الصحة العالمية، البُلد العاشر، العددان ع-0، ع • •? 


\section{Introduction}

Malaria is the most important problem of developing countries. According to the latest report, it kills between 1.5-2.7 million people every year [1]. Malaria has always been considered as the most important vector-borne disease in the Islamic Republic of Iran due to its socioeconomic effects on the population [2].

Since the discovery of the insecticide dichloro-diphenyl-trichloroethane (DDT) before the Second World War, the widespread use of synthetic insecticides for the control of pests as well as human disease vectors has led to concerns about their toxicity and environmental impact [3]. Because of this, the search for new environmentally safe, target-specific insecticides is active throughout the world. To find new modes of action and to develop active agents based on natural plant products, efforts are being made to isolate, screen and develop phytochemicals possessing pesticidal activity. These categories of pesticides are known as biopesticides [3].

The neem tree (Azadirachta indica) is a member of the mahogany family (Meliacea) that is native to India and Burma, but it was introduced to other countries in the late 19th century [4]. Six species in the family Meliacea have been studied for pesticidal properties in different parts of the world. They are Azadirachta indica Juss, A. excelsa Jack, A. siamens Valeton, Melia azadirachta L., M. toosendan Sieb. and Zucc. and M. volkensii Gurke [3]. However, the most promising phytochemical pesticides studied in recent years are those based on extracts of Az. indica [3].

Various neem products have been researched extensively for their phytochemistry and exploitation in pest control programmes [3]. A number of bioactive components have been isolated from various parts of the neem tree. These chemical compounds have different designations, among which azadirachtin $\mathrm{A}$ is the major component. In addition to azadirachtin, a number of other active ingredients have also been isolated and identified from different parts of the neem tree, such as salannin, meliantriol and nimbin [3,4]. Two new triterpenoids (22,23-dihydronimocinol and des-furano-6-alpha-hydroxyazadiradione) were isolated from a methanolic extract of the fresh leaves of $A z$. indica along with a known meliacin, 7-alpha-senecioyl-(7deacetyl)-23-O-methylnimocinolide [5].

Neem components show multiple effects against different insects such as mosquitoes, flies, triatomine bugs, cockroaches, fleas, lice and ticks [3,4]. The effect of neem on the activity of insects has been neglected up to now, possibly because it does not rapidly lead to mortality. However, affected insects cannot survive adverse environmental conditions in the same way as normal, healthy individuals; for example insects with reduced activity (reduced sight, jumping, crawling and flying ability) may be caught more easily by natural predators. Because of the variety of components and different mechanisms of action, insect resistance to neem compounds seems likely to be low [8-10].

The repellent activity of neem oil solutions in coconut oil against populations of mosquitoes consisting mainly of Mansonia spp. in Gambella, western Ethiopia, was demonstrated by Hadis et al. [6]. The aim of the present study was to evaluate the efficacy and durability of a neem extract against the main mosquito species in the southern part of the Islamic Republic of Iran. 


\section{Methods}

Laboratory and field trials were carried out using an azadirachtin-rich product, Neemarin 0.15\% (Biotech International Limited, New Delhi, India). The formulation consists of active ingredient $(0.15 \%$ $\mathrm{w} / \mathrm{w})$, inert material $(1.35 \% \mathrm{w} / \mathrm{w})$ and propylene glycol $(98.5 \% \mathrm{w} / \mathrm{w})$.

\section{Laboratory tests}

Larvae of laboratory-reared strains of Anopheles stephensi and Culex quinquefasciatus (originally from the Bandar-e-Abass city area) were tested with different concentrations of Neemarin at the late 3rd instar and early 4th instar stages in a room at $25^{\circ} \mathrm{C} \pm 1{ }^{\circ} \mathrm{C}$ in autumn and winter 1999 , according to WHO methods [11]. The strains are susceptible to different insecticides such as DDT, organophosphates, carbamates and pyrethroids. Preliminary testing was carried out to establish suitable concentrations. Selected stock solutions of Neemarin after preliminary tests were as follows: 0.0586, 0.117, 0.234, 0.469, $0.938,1.875$, and $3.750 \mathrm{mg} / \mathrm{L}$. Lower logarithmic concentrations of Neemarin were diluted by adding the required volume of alcohol solvent to the main stock of Neemarin.

At each concentration, 200 mosquitoes representing individuals of 25 larvae were tested on 4 occasions. Each test run consisted of $74 \mathrm{~mL}$ water, $1 \mathrm{~mL}$ of Neemarin stock solution (by use of sampler) and then 25 larvae in $25 \mathrm{~mL}$ water were added, so that the final volume was $100 \mathrm{~mL}$. In control runs, $1 \mathrm{~mL}$ alcohol was added instead of Neemarin.

Mortality counts were made every 24 hours after exposure until the test was terminated (when all the adults had emerged). In the analysis, both dead and moribund larvae were considered as dead, and the numbers alive at different stages (larvae, pupae, adults) were scored separately. The percentage mortality in the treated larvae was corrected relative to the controls using Abbotts formula [11]. The data were subjected to probit regression analysis according to Finney [12]. Goodness of fit of the points to a straight line was tested by chisquared analysis.

\section{Field trials}

Field trials were carried out in artificial ponds $(100 \times 30 \times 50 \mathrm{~cm})$ in Jadas, Kazeroun, in the south-eastern part of the Islamic Republic of Iran in summer 2000, according to the method of Mulla and WHO recommendations [11,13]. The ponds were constructed separately, without vegetation and were exposed to sunlight.

Replicate ponds were created for each treatment: 2 control ponds and 4 treatment ponds. In the treatment ponds, Neemarin was sprayed on the water surface using a manual sprayer at 2 different concentrations (1 L/hectare and $2 \mathrm{~L} /$ hectare), as recommended by other researchers $[9,14]$.

The number of larvae in the artificial ponds before and after the application of Neemarin (up to 10 days) were counted using a standard dipper. The frequency of Anopheles and Culex spp. larvae were counted using the method of Mulla with a cubic metal frame incorporated into the net for keeping and counting larvae in artificial ponds [13].

The larvae were identified according to the national identification key described by Shahgudian [15].

\section{Results}

\section{Laboratory tests}

Using probit regression analysis software, regression lines were plotted for the dose-

لبحلة الصحية لشرق المثتوسط، منظمة الصحة العالمية، البحلد العاشر، العددان ع-0، ع • • 
response to Neemarin treatment of laboratory strains of An. stephensi and $C x$. quinquefasciatus larvae (Figures 1 and 2). For An. stephensi the $\mathrm{LC}_{50}$ (lethal concentration to cause $50 \%$ mortality in the population) was measured as $0.35 \mathrm{mg} / \mathrm{L}$ and the $\mathrm{LC}_{90}$ (lethal concentration to cause $90 \%$ mortality in the population) was $1.81 \mathrm{mg} / \mathrm{L}$. For $C x$. quinquefasciatus the $\mathrm{LC}_{50}$ was 0.69 $\mathrm{mg} / \mathrm{L}$ and $\mathrm{LC}_{90}$ was $3.18 \mathrm{mg} / \mathrm{L}$ respectively (Table 1). Thus, An. stephensi larvae needed a significantly lower concentration of Neemarin than $C x$. quinquefasciatus to cause the same mortality $(P<0.05)$.

The mortality among the pupal stages was greater than other stages $(P<0.05)$. For example, among 400 larvae of Anopheles species tested at the highest concentration, the mortality rate of larvae, pupae and adults were $15.8 \%, 79.8 \%$ and $40.3 \%$ respectively. Similar data were obtained for other concentrations and for Culex species. Inhibition of adult emerged larvae through mortality of pupae was the main action of Neemarin.

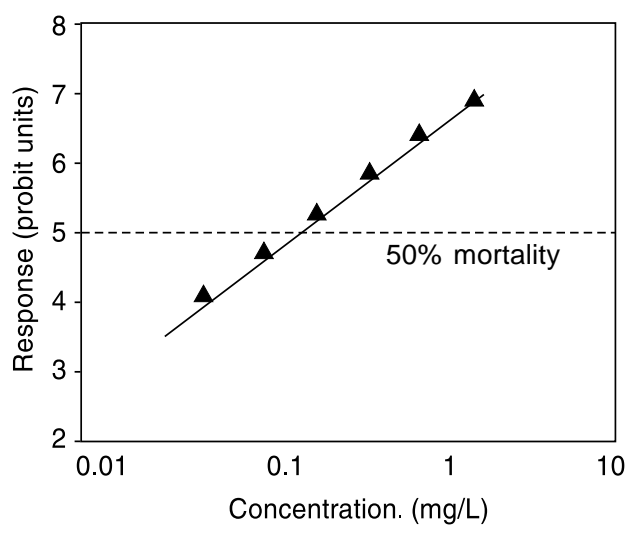

Figure 1 Probit regression line for response of Anopheles stephensi larvae to Neemarin treatment in laboratory tests

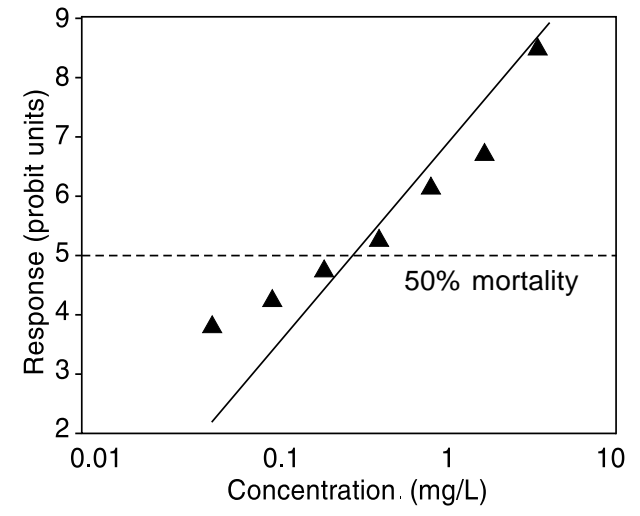

Figure 2 Probit regression line for response of Culex quinquefasciatus larvae to Neemarin treatment in laboratory tests

\section{Field trials}

In the field trials in artificial ponds, the distribution of species identified during the first run of the test were An. stephensi (29\%), An. fluviatilis (27\%), An. dthali (13\%), An. superpictus (6\%) and Culex spp. (25\%) for 500 mosquito larvae. During the second run of the test the species were as follows: An. stephensi (26\%), An. dthali (22\%), An. superpictus (13\%) and Culex spp. (38\%) for 450 mosquito larvae.

Tables 2 and 3 show the mortality rates of Anopheles and Culex spp. at different stages (larvae, pupae, adult), comparing controls with 2 different concentrations of Neemarin treatment (combining the 2 replicate runs). The main indicator of treatment response was the percentage inhibition of emerged adults. The inhibitory effect of Neemarin declined over the 3 days of treatment. For Anopheles species, inhibition of emerged adults fell from $33 \%$ and $56 \%$ at 1 $\mathrm{L} /$ hectare and $2 \mathrm{~L} /$ hectare after 1 day to $5 \%$ and 20\% respectively after 3 days. For Culex species, inhibition of emerged adults fell from $30 \%$ and $46 \%$ at $1 \mathrm{~L} /$ hectare and 2

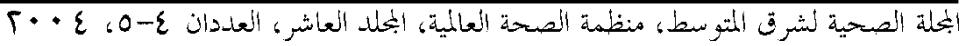


\begin{tabular}{ll}
\hline Eastern Mediterranean Health Journal, Vol. 10, Nos 4/5, 2004 & 577
\end{tabular}

Table 1 Probit regression line parameters of response of Anopheles stephensi and Culex quinquefasciatus to Neemarin treatment in laboratory tests

\begin{tabular}{lccccccccc}
\hline $\begin{array}{l}\text { Mosquito } \\
\text { species }\end{array}$ & Intercept Slope (SE) & $\begin{array}{c}\mathbf{L} \boldsymbol{C}_{50} \\
(\mathbf{m g} / \mathbf{L})\end{array}$ & $95 \% \boldsymbol{C l}$ & $\begin{array}{c}\mathbf{L} \boldsymbol{C}_{\boldsymbol{9 0}} \\
(\boldsymbol{m g} / \mathbf{L})\end{array}$ & $95 \% \boldsymbol{C l}$ & $\chi^{2}(\boldsymbol{d f})$ & $P$-value \\
\hline An. stephensi & 1.31 & $1.78(0.07)$ & 0.35 & $0.18-0.37$ & 1.81 & $0.96-2.05$ & $26.70(4)$ & $<0.0001$ \\
Cx. quinquefasciatus & 0.85 & $1.91(0.06)$ & 0.69 & $0.36-0.74$ & 3.18 & $1.68-3.38$ & $29.08(5)$ & $<0.0001$ \\
\hline
\end{tabular}

$S E=$ standard error.

$L C_{50}=$ lethal concentration to cause $50 \%$ mortality in population.

$L C_{90}^{50}=$ lethal concentration to cause $90 \%$ mortality in population.

$\mathrm{Cl}=$ confidence interval.

$\chi^{2}(d f)=$ heterogeneity about the regression line (degrees of freedom).

L/hectare after 1 day to $1 \%$ and $21 \%$ respectively after 3 days. The frequency of larvae in the artificial ponds were different before and after application and increased after 7 days in all replicates, that shows maximum time of efficacy and inhibition of emerged adults at 7 days after application did not show a significant difference $(P<$ $0.05)$. The maximum time of efficacy was 7 days at the $2 \mathrm{~L} /$ hectare concentration
$(P<0.05)$. The durability of the product depended on the dosage applied $(P<0.05)$.

As in the laboratory tests, pupal mortality was higher than the other stages for Anopheles (Table 2) and Culex spp. (Table 3). A lower concentration of Neemarin was needed for Anopheles spp. larvae than for Culex spp. to cause the same mortality $(P<$ 0.05).

\begin{tabular}{lccccccc}
\hline \multicolumn{6}{l}{$\begin{array}{l}\text { Table } 2 \text { Mortality of Anopheles spp. at different stages in artificial ponds, } \\
\text { comparing controls with } 2 \text { different concentrations of Neemarin }\end{array}$} \\
\hline $\begin{array}{l}\text { Time after } \\
\text { treatment }\end{array}$ & $\begin{array}{c}\text { Larvae } \\
\text { tested } \\
\text { No. }\end{array}$ & $\begin{array}{c}\text { Larvae } \\
\%\end{array}$ & $\begin{array}{c}\text { Mortality rate } \\
\text { Pupae } \\
\text { Adults } \\
\%\end{array}$ & $\begin{array}{c}\text { Total } \\
\%\end{array}$ & $\begin{array}{c}\text { Survival } \\
\text { rate } \\
\%\end{array}$ & $\begin{array}{c}\text { Inhibition } \\
\text { (SE) } \\
\%\end{array}$ \\
\hline 1 day & & & & & & & \\
Controls & 93 & 7 & 8 & 3 & 18 & 82 & \\
1 L/hectare & 130 & 18 & 22 & 5 & 45 & 55 & $33(4.1)$ \\
2 L/hectare & 272 & 24 & 29 & 11 & 64 & 36 & $56(2.9)$ \\
2 days & & & & & & & \\
Controls & 90 & 9 & 6 & 3 & 18 & 82 & \\
1 L/hectare & 160 & 10 & 18 & 3 & 31 & 69 & $16(3.6)$ \\
2 L/hectare & 337 & 14 & 27 & 10 & 51 & 49 & $40(2.7)$ \\
3 days & & & & & & & \\
Controls & 105 & 12 & 14 & 5 & 18 & 82 & \\
1 L/hectare & 200 & 6 & 9 & 2 & 17 & 78 & $5(2.6)$ \\
2 L/hectare & 310 & 11 & 18 & 5 & 34 & 66 & $20(2.6)$ \\
\hline
\end{tabular}

a Percentage inhibition of adult emerged larvae comparing treatment with controls. $S E=$ standard error.

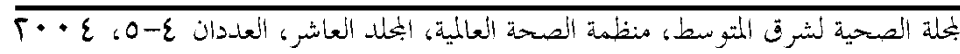


Table 3 Mortality of Culex spp. at different stages in artificial ponds, comparing controls with 2 different concentrations of Neemarin

\begin{tabular}{lccccccc}
\hline $\begin{array}{l}\text { Time after } \\
\text { treatment }\end{array}$ & $\begin{array}{c}\text { Larvae } \\
\text { tested } \\
\text { No. }\end{array}$ & $\begin{array}{c}\text { Larvae } \\
\%\end{array}$ & $\begin{array}{c}\text { Mortality rate } \\
\text { Pupae } \\
\%\end{array}$ & $\begin{array}{c}\text { Adults } \\
\%\end{array}$ & $\begin{array}{c}\text { Total } \\
\%\end{array}$ & $\begin{array}{c}\text { Survival } \\
\text { rate } \\
\%\end{array}$ & $\begin{array}{c}\text { Inhibition } \\
\text { (SE) } \\
\%\end{array}$ \\
\hline 1 day & & & & & & & \\
$\quad$ Controls & 61 & 7 & 4 & 2 & 13 & 87 & \\
1 L/hectare & 50 & 14 & 22 & 3 & 39 & 61 & $30(4.2)$ \\
2 L/hectare & 75 & 16 & 26 & 11 & 53 & 47 & $46(5.3)$ \\
2 days & & & & & & & \\
$\quad$ Controls & 45 & 5 & 5 & 7 & 17 & 83 & \\
1 L/hectare & 60 & 5 & 15 & 1 & 21 & 79 & $5(4.3)$ \\
2 L/hectare & 90 & 8 & 20 & 6 & 34 & 66 & $20(4.2)$ \\
3 days & & & & & & & \\
$\quad$ Controls & 54 & 6 & 7 & 0.4 & 13 & 87 & \\
1 L/hectare & 51 & 5 & 8 & 1 & 14 & 86 & $1(3.6)$ \\
2 L/hectare & 110 & 8 & 18 & 5 & 31 & 69 & $21(3.8)$ \\
\hline
\end{tabular}

aPercentage inhibition of adult emerged larvae comparing treatment with controls. $S E=$ standard error.

The findings of the present study were compared with other researchers' results using different neem extract formulations (Neemazal, ANSKE, AZT-VR-K-E and MTB) on Aedes aegypti mosquitoes. The $\mathrm{EC}_{50}$ for above formulations (molar concentration of product which produces $50 \%$ of the maximum possible response) were 8.4, 78.2, 18.1 and $5.9 \mathrm{ppm}$ respectively (Table 4).

\section{Discussion}

Neem products are capable of producing multiple effects on a number of insect species, such as anti-feeding effects, growth regulation, fecundity suppression and sterilization, oviposition repellency or attractancy and changes in biological fitness [3].

In some cases, neem has repellent effects. For example, the percentage protection against sand fly bites provided by neem oil was significantly higher than N,N-diethyphenylacetamide (DEPA) when applied at $1 \%$ and $2 \%$ concentrations $[16,17]$. Neem extracts have been shown to have repellent activity against Mansonia spp. mosquitoes in Gambella, western Ethiopia [5].

Studies on the anti-feeding activity of the neem extracts showed that crops treated with an aqueous suspension of neem seeds were protected from attack by locusts. Host plant selection is mainly governed by the responses of the insect's gustatory and olfactory sensilla. Since azadirachtin is non-volatile, the specificity and responsiveness of receptors on the insect's taste neurons are likely to be critically important in this process.

The effects of neem products on the reproduction of insects have been known since 1975 and reproduction reduction effects have been found in Caelifera,

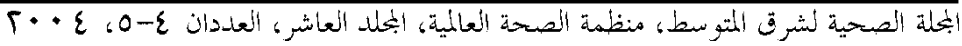


Table 4 Comparison of effectiveness of different neem formulations in laboratory tests on mosquito species

\begin{tabular}{lccc}
\hline Mosquito species & $\begin{array}{c}\text { Neem } \\
\text { formulation }\end{array}$ & $\begin{array}{c}E C_{50} \\
(\mathbf{p p m})\end{array}$ & Reference \\
\hline Aedes aegypti & Neemazal & 8.4 & {$[11]$} \\
Ae. aegypti & ANSKE & 78.2 & {$[11]$} \\
Ae. aegypti & AZT-VR-K-E & 18.1 & {$[11]$} \\
Ae. aegypti & MTB & 5.9 & {$[11]$} \\
Anopheles stephensi & Neemark & 0.05 & {$[6]$} \\
Culexquinquefasciatus & Neemark & 0.22 & {$[6]$} \\
An. stephensi & Neemarin & 0.18 & Present study \\
Cx. quinquefasciatus & Neemarin & 0.36 & Present study \\
\hline
\end{tabular}

Neemazal (Trifolio-M GmbH, Lahnau, Germany) $10 \mathrm{~g} / \mathrm{L}$ azadirachtin. ANSKE = aqueous neem seed kernel extract.

$A Z T-V R-K-E$ = enriched and formulated neem seed kernel extract. $M T B=$ neem seed extract.

Neemarin (Biotech International Limited, New Delhi, India) 0.15\% azadirachtin.

$E C_{50}=$ molar concentration of product which produces $50 \%$ of the maximum possible response.

Heteroptera, Homoptera, Hymenoptera, Lepidoptera and Diptera [3,9]. A large number of abortions (dead-born larvae) in the tsetse flies Glossina morsitans morsitans and Glossina pallidipes after treatment of pregnant females with neem oil and the azadirachtin-enriched neem seed kernel extract AZT-VR-K were found.

In mosquitoes, compounds extracted from $A z$. indica showed mortality for fourth instar larvae of An. stephensi, with $\mathrm{LC}_{50}$ values of 60 and $43 \mathrm{ppm}$, respectively [4]. This compares with the $\mathrm{LC}_{50}$ and $\mathrm{LC}_{90}$ in our study of 0.36 and $1.81 \mathrm{ppm}$ for $A n$. stephensi and 0.69 and $3.18 \mathrm{ppm}$ for $C x$. quinquefasciatus respectively using a commercial preparation of neem extract, Neemarin. Our results were comparable with findings from other researchers as shown in Table 4. The variation in $\mathrm{LC}_{50}$ is due to mosquito species, formulation, climate and method of application.
In order to compare the larvicidal effect of Neemarin with WHO-recommended larvicides (malathion, fenitrothion, temephos, chlorpyrifos), the regression lines were compared. This showed that the toxicity of Neemarin is less than other chemicals and the $\mathrm{LC}_{50}$ and $\mathrm{LC}_{90}$ of Neemarin on laboratory strains of $A n$. stephensi were to some extent similar to temephos [1].

Neem extracts act like insect growth regulators, so the mortality at different stages were considered. Mortality of the pupae stage was significantly higher than the larvae and adult stages. In addition, the mortality of $C x$. quinquefasciatus was significantly lower than An. stephensi.

We conclude that Neemarin, at the recommended concentrations in field studies of 1 and 2 L/hectare, significantly reduces the frequency of larvae and the estimated residual effect is 7 days.

لبحلة الصحية لشرق المثتوسط، منظمة الصحة العلمية، البحلد العاشر، العدذان ع-0، ع • • 


\section{Acknowledgements}

We would like to thank all of the staff members of the Medical Entomology Depart- ment and Giahpezeshk Limited for their kind collaboration.

\section{References}

1. Report of the fourth meeting of the global collaboration for development of pesticides for public health. Geneva 24-25 June, 2004. Geneva, World Health Organization, 2004 (WHO/CDS/WHOPES / GCDPP/2004.8).

2. Zaim M. Malaria control in Iran, present and future. Journal of the American Mosquito Control Association, 1987, 3:3926.

3. Mulla MS, Su T. Activity and biological effects of Neem products against arthropods of medical and veterinary importance. Journal of the American Mosquito Control Association, 1999, 15(2): 133-52.

4. Ruskin FR. Neem: a tree for solving global problems. Washington DC, National Academy Press, 1992.

5. Siddiqui BS et al. Two new triterpenoids from Azadirachta indica and their insecticidal activity. Journal of natural products, 2002, 65(8):1216-8.

6. Hadis $\mathrm{M}$ et al. Field trials on the repellent activity of four plant product against mainly Mansonia population in western Ethiopia. Phytotherapy research, 2003, 17(3):202-5.

7. Sharma SK, Sharma VP. Field studies on the mosquito repellent action of neem oil. Southeast Asian journal of tropical medicine and public health, 1995, 26(1): 180-2.

8. Sharma VP, Dhiman RC. Neem oil as a sandfly (Diptera: Psycodidae) repellent. Journal of the American Mosquito Control Association, 1993, 9:364-6.
9. Dhar R et al. Effect of volatiles from neem and other natural products on gonotrophic cycle and oviposition of Anopheles stephensi and An. culicifacies (Diptera:Culicidae). Journal of medical entomology, 1996, 33:195-201.

10. Rao DR, Reuben R. Evaluation of neem cake power and neem cake coated urea as mosquito larvicides in rice fields. In: Uren MF, Block J, Manderson LH, eds. Arbovirus research in Australia. Proceedings of the Fifth Symposium $28 \mathrm{Au}$ gust to 1 September 1989. Brisbane, Australia, CSIRO Tropical Animal Science, 1989:138-42.

11. Instructions for determining the susceptibility or resistance of mosquito larvae to insect development inhibitors. Geneva, World Health Organization, 1981 (WHO/ VBC/81.812).

12. Finney DJ. Probit analysis, 3rd ed. New York, Cambridge University Press, 1971.

13. Mulla M.S. Insect growth regulators for the control of mosquito pests and disease vectors. Chinese journal of entomology, 1991, 6:81-91.

14. Boschitz C, Grunewald J. The effect of NeemAzal on Aedes aegypti (Diptera: Culicidae). Applied parasitology, 1994, 35(4):251-6.

15. Shahgudian ER. A key to the Anophelines of Iran. Acta medica Iranica, 1960, $3(3): 38-48$.

16. Srinivasan R, Kalyanasundaram M. Relative efficacy of DEPA and neem oil for repellent activity against Phlebotomus papatasi, the vector of leishmaniasis.

بلملة الصحية لشرق المثتوسط، منظمة الصححة العلمية، المجلد العاشر، العددان ع-0، ع • •؟ 
Journal of communicable diseases, 2001, 33(3):180-4.

17. Parida $\mathrm{MM}$ et al. Inhibitory potential of neem (Azadirachta indica Juss) leaves on dengue virus type-2 replication. Journal of ethnopharmacology, 2002, 79(2): 273-8.

\section{Malaria control in the Eastern Mediterranean Region}

Significant progress was made in 2003 with the development of appropriate technical guidelines for the improvement of key strategies for the control of malaria and other vector-borne diseases. These included the regional strategic framework for integrated vector management, guidelines on monitoring insecticide resistance, regional guidelines on the management of public health pesticides, including country profiles, and guidelines on malaria microscopy and quality assurance. The WHO publications Instructions for treatment and use of insecticide-treated mosquito nets and Basic malaria microscopy were translated into Arabic. Mational strategic plans on use of insecticide-treated nets were finalized for Afghanistan, Djibouti, Saudi Arabia, Sudan and Yemen. A regional network for monitoring vector resistance was initiated and country-level partnership was fostered at the annual meeting of national malaria programme managers held in Lahore, Pakistan in June 2003.

Source: The Work of WHO in the Eastern Mediterranean Region. Annual Report of the Regional Director 1 January-31 December 2003 Available at: http://www.emro.who.int/rd/AnnualReports/2003/index.htm

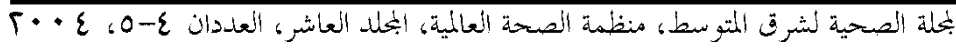

